\title{
Evolution of Citrus Disease Management Programs and Their Economic Implications: The Case of Florida's Citrus Industry ${ }^{1}$
}

\author{
Ariel Singerman and Marina Burani-Arouca²
}

\section{Introduction}

This article focuses on the costs of managing exotic citrus diseases as they become endemic or established within a citrus industry, with Florida used as an example. In particular, the figures in this article represent the cost of production for processed juice oranges in the southwest Florida region and fresh market grapefruit in the Indian River region (Figure 1). Before 2004, average annual pest control consisted of two sprays for processed juice fruit and six sprays for fresh market grapefruit. The purpose of such sprays was to control for diseases and pests, including greasy spot, scab, melanose, rust mites, and weevils. After four hurricanes hit the state in 2004/05 and the citrus canker eradication program ended in 2006, the number of sprays to manage canker and other diseases increased to 3-4 for processed juice oranges and 10 for fresh market grapefruit. With the discovery of Huanglongbing (HLB, citrus greening) in Florida in 2005 and citrus black spot in 2010 (for the case of processed fruit), annual pest control increased to 8-9 sprays for processed juice fruit and 14 sprays for fresh market grapefruit. Throughout this article, we remove inflationary effects to focus exclusively on the change in practices. Thus, all costs are expressed in real terms using 2015 US dollar values.

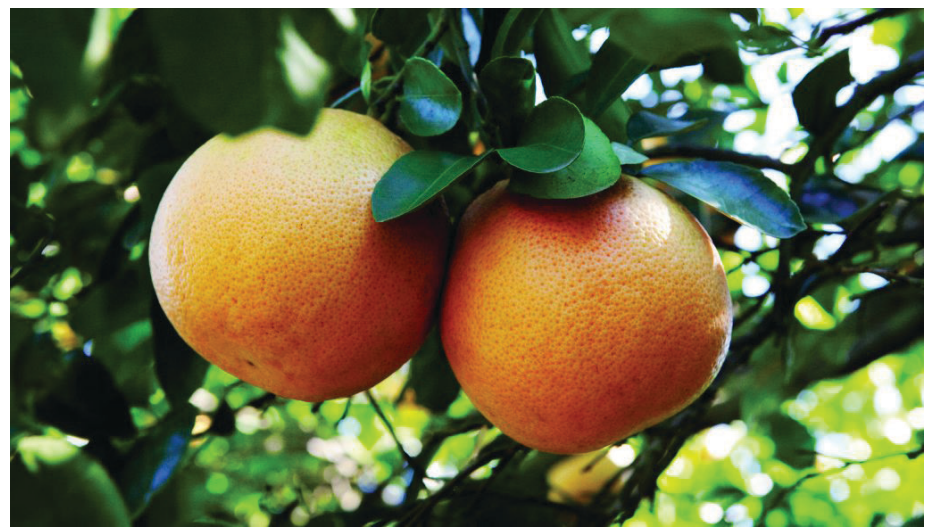

Credit: USDA

\section{Economic Implications of Citrus Disease Mangement Programs}

Annual citrus cost budgets have been published for three Florida citrus production regions for over 25 years and are the source used for the analysis we present (Muraro 2004a, 2004b; Singerman 2015a, 2015b).

Before 2005, citrus blight and citrus tristeza were major diseases that caused concerns for Florida citrus growers. Both diseases restrict the uptake of nutrients from the roots to the tree canopies, resulting in a decline in tree health and economic productivity. Unfortunately, there

1. This document is FE915, one of a series of the Department of Food and Resource Economics, UF/IFAS Extension. First published October 2012 by Ronald Muraro, professor and Extension economist; revised January 2017. Visit the EDIS website at https://edis.ifas.ufl.edu.

2. Ariel Singerman, assistant professor; and Marina Burani-Arouca, economics research and extension coordinator; Department of Food and Resource Economics, UF/IFAS Citrus Research and Education Center, Lake Alfred, FL. 
were no pesticide applications that could suppress these diseases. For other diseases and pests, including greasy spot, scab, melanose, rust mites, and diaprepes weevils, pest-management and spray programs for processed juice fruit consisted of two to three annual sprays and six annual sprays for fresh market grapefruit.

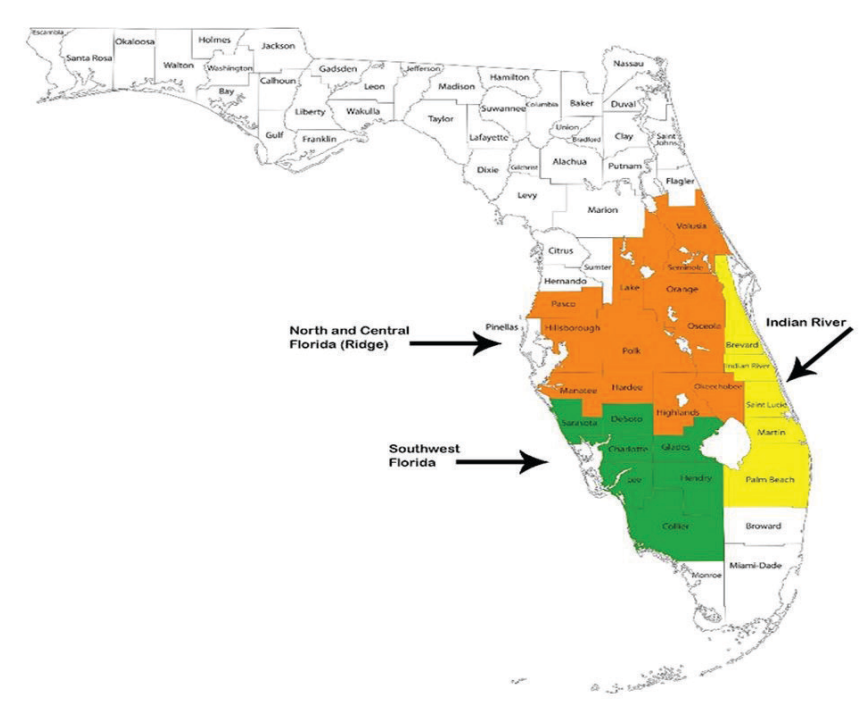

Figure 1. Three primary citrus-production regions in Florida (north and central Ridge, southwest, Indian River)

\section{Citrus Canker}

Citrus canker has been a serious concern in commercial citrus groves in Florida since an outbreak was detected in south Florida in 1995. In response to the citrus canker outbreak, the Florida Department of Agriculture and Consumer Services (FDACS) Division of Plant Industry (DPI) and the United States Department of Agriculture (USDA) implemented an eradication program. The program originally called for the removal and destruction of diseased trees as well as any other citrus trees within a 125 -foot radius of the affected tree. In 2000, the eradication radius was extended to 1900 feet. However, homeowners in certain Florida counties challenged this new rule and its constitutionality to temporarily halt the eradication program, which favored the spread of the disease (Gottwald et al. 2002).

During 2004 and 2005, four hurricanes and one tropical storm with strong winds and rain crossed Florida, resulting in widespread dispersion of citrus canker throughout the state's main citrus production regions. In 2006, Florida's citrus canker eradication program was terminated when citrus canker was classified as endemic in the state. Growers began managing citrus canker with additional copper sprays: one spray for Valencia oranges (which are less susceptible to citrus canker), two additional sprays for Hamlin oranges, and four additional copper sprays for fresh market grapefruit. In some locations, natural windbreaks were planted as part of the canker management program for fresh market citrus. To comply with fresh market regulatory rules imposed by the USDA and foreign markets, particularly Europe, fresh market citrus growers had to certify that groves and fruit packed in cartons were free of canker.

\section{HLB / Citrus Greening}

In 2005, HLB was found in Florida. By 2006, growers began implementing an HLB management program advocated by Sao Paulo (Brazil) growers who had discovered HLB 18 months earlier in their groves. The standard HLB program consisted of spraying to control the Asian citrus psyllid (the insect that transmits the disease), scouting every tree at least four times a year to locate HLB symptoms, and eliminating symptomatic trees as soon as possible. By 2010, most Florida growers had stopped eradicating symptomatic trees, but remained focused on spraying to control psyllids. In addition, by 2012, a significant proportion of the Florida citrus industry had moved rapidly toward the use of various versions of the Enhanced Foliar Nutritional Program (EFNP) to try to maintain the health and productivity of trees (Gottwald et al. 2012). Although initial observations from growers were that HLB-symptomatic tree yields had stopped declining and in some cases had increased slightly, citrus yield statewide was actually on a downward trend as many growers continue to reset/replant trees. Before 2005, the typical annual tree mortality rate had been about $3 \%$. The additional annual tree-loss rate due to HLB has been estimated at $2 \%$. Survey data regarding replacement rates collected by Singerman (2015a) show the estimate of 5\% for annual tree loss is still valid.

In 2010, Citrus Health Management Areas (CHMAs) began to be organized. The purpose of CHMAs is to encourage neighboring citrus growers to work cooperatively to combat HLB, particularly through the coordination of psyllid control efforts. Local CHMAs encourage coordinated sprays to provide enhanced psyllid management over a wide geographical area as compared to individual actions. In 2012, there were 35 CHMAs formed in Florida. At the end of 2015, there were 55 CHMAs but only 19 were estimated to be active. Aerial and ultra-low-volume spray applications have been incorporated into psyllid control programs. Thus, the processed spray program increased to 11 sprays for processed oranges, and 14 sprays for fresh market grapefruit. 


\section{Black Spot}

In 2010, citrus black spot was found in a southwest Florida citrus grove. It is suspected that this disease was introduced in the grove several years before environmental conditions enabled the disease to fully express itself. Although citrus black spot does not affect the internal quality of the fruit, it causes excessive fruit drop in both young and mature groves if left unchecked. Black spot is problematic for fresh fruit production because it is a quarantine disease for several major markets, especially the European Union. Fortunately, it has not yet been found in any Florida fresh fruit production groves where the fruit is destined for export. As of the end of 2015/16, the disease was confined to three counties, Collier (southwest Florida), Hendry (southwest Florida), and Polk County (central Florida). Lee County (southwest Florida) has quarantine zones, but no disease has yet been found. The concern is that this disease will eventually spread throughout all Florida's commercial citrus-producing regions.

The current recommendation for black spot disease control includes between 4 and 6 monthly sprays, alternating between copper and other fungicides (Dewdney et al. 2015). These chemicals can be included with other sprays to control citrus canker and the Asian citrus psyllid. However, at least 1 or 2 additional high-volume ground sprays are likely to be needed to manage black spot.

\section{Changes in Production Costs for Citrus in Florida}

Since 2005, total costs and, specifically, spray costs have increased in Florida because the citrus industry has gone from dealing with just a few diseases to managing exotic diseases, such as citrus canker, HLB, and citrus black spot. The 2003/04 cultural costs per acre for producing processed oranges in southwest Florida without tree replacement was $\$ 936.87$; foliar sprays and fertilization accounted for $\$ 185.63$ and $\$ 207.69$ per acre, respectively. In $2014 / 15$, the cultural cost per acre in that region was $\$ 1,651.34$, and the cost of foliar sprays and fertilization were $\$ 666.00$ and $\$ 486.96$ per acre, respectively (Table 1$)$. Thus, since $2003 / 04$, the cost of the foliar spray program alone increased by almost $260 \%$, and that of fertilizer increased by $134 \%$.

The 2003/04 cultural cost for fresh market grapefruit in the Indian River region was $\$ 1,366.75$ per acre without tree replacement. Foliar sprays and fertilization accounted for $\$ 493.08$ and $\$ 190.56$ per acre, respectively. In 2014/15, the cultural cost of production was $\$ 2,247.43$ per acre; foliar sprays and fertilization that year accounted for $\$ 1,300.40$ and $\$ 452.55$ per acre, respectively. Hence, in this case, the increase in the cost of foliar sprays and fertilizer programs were $164 \%$ and $137 \%$, respectively (Table 2 ). The nominal increase in costs was driven partly by higher input costs such as fuel/energy, chemicals, and fertilizer, but the change in real cost (as shown in this article) was driven by the change in cultural practices to control the new pests and diseases described above.

With the introduction of exotic diseases, the tree-loss rate also increased by $2 \%$ to approximately $5 \%$ in $2014 / 15$. Tree replacement can become a costly program within the orchard management program, varying greatly with the amount of trees per acre being reset. In 2003/04, the average number of resets in southwest Florida was 4 trees per acre. The tree replacement program at that time totaled $\$ 145.98$ per acre, or $\$ 36.49$ per tree (Table 1). In $2014 / 15$, the number of resets was 9 trees per acre, and growers spent, on average, $\$ 346.77$ per acre, or $\$ 38.53$ per tree. Thus, the increase in the tree replacement program is mostly driven by the higher mortality rate.

Grapefruit growers in the Indian River region reset an average of 5 trees per acre in 2003/04, with a total replacement cost per acre of $\$ 182.47$, or $\$ 36.49$ per tree (Table 2). In $2014 / 15$, the average number of resets increased to 6 per acre, totaling $\$ 231.18$ per acre, or $\$ 38.53$ per tree. The difference in the number of trees reset by grapefruit growers in the Indian River region and processed orange growers in southwest Florida could be attributed to the different tree densities in the two areas for the two citrus varieties.

\section{Summary}

There has been a sharp increase in the real cost of production of citrus in Florida driven by the management of new exotic diseases; namely, citrus canker, HLB, and citrus black spot. Costs for managing citrus canker increased due to the need to spray copper at 21-day intervals (approximately from April to August depending on the variety) to minimize fruit drop and blemishes on fruit for the fresh fruit markets. To a lesser extent, processed orange varieties such as Hamlin and Valencia also require copper sprays to protect them from excessive fruit drop.

In their attempt to cope with HLB, growers have been applying different management strategies such as EFNP, coordinated insecticide sprays, and heat treatments. More effective treatments are being researched. The costs and benefits of these alternatives will need to be quantified to establish their economic feasibility. 
Citrus black spot is a major concern to Florida citrus growers that, it is hoped, may be contained through effective sanitation methods for personnel and equipment in infected groves and by covering fruit transport trailers with tarps. Growers who employ these sanitation procedures and perform the additional sprays to control black spot incur higher production/cultural costs and need to obtain higher fruit prices to cover their higher costs.

The steep increase in the real cost of production of citrus in Florida from 2003/04 to 2014/15 provides evidence that managing endemic exotic diseases is very costly for growers, even without taking into account the effect those diseases have on yields. Therefore, governmental policies focused on preventing the introduction of additional exotic diseases-such as citrus variegated chlorosis (CVC) and citrus leprosis virus (CiLV) - would be highly beneficial for citrus growers and the Florida citrus industry as a whole.

\section{References}

Dewdney, M.M., T.S. Schubert, M.R. Estes, P.D. Roberts, and N.A. Peres. 2015. "Citrus black spot." In M.E. Rogers and M. M. Dewdney (editors), 2016 Florida Citrus Pest Management Guide. Gainesville, FL: University of Florida Institute of Food and Agricultural Sciences. https://crec.ifas. ufl.edu/extension/pest/PDF/Citrus\%20Black\%20Spot.pdf

Gottwald, T.R., J.H. Graham, M.S. Irey, T.G. McCollum, and B.W. Wood. 2012. "Inconsequential Effect of Nutritional Treatments on Hunaglongbing Control, Fruit Quality, Bacterial Titer, and Disease Progress." Crop Protection 36: 73-82

Gottwald, T.R., J.H. Graham, and T.S. Schubert. 2002. "Citrus Canker: The Pathogen and Its Impact." Plant Health Progress doi: 10.1094/PHP-2002-0812-01-RV. http://www. apsnet.org/publications/apsnetfeatures/Pages/citruscanker. aspx

Muraro, R. P. 2004a. Summary of 2003-2004 Citrus Budgets for the Southwest Florida Production Region. Lake Alfred, FL: University of Florida Institute of Food and Agricultural Sciences. http://www.crec.ifas.ufl.edu/extension/economics/ pdf/SouthwestFloridaSum04.pdf

Muraro, R. P. 2004b. Summary of 2003-2004 Citrus Budgets for the Indian River Production Region. Lake Alfred, FL: University of Florida Institute of Food and Agricultural Sciences. http://www.crec.ifas.ufl.edu/extension/economics/ pdf/IndianRiverSum04.pdf
Singerman, A. 2015a. 2014/15 Southwest Florida Cost of Production for Processed Oranges. Lake Alfred, FL: University of Florida Institute of Food and Agricultural Sciences. http://www.crec.ifas.ufl.edu/extension/economics/ pdf/2014_15\%20Southwest\%20Costs.pdf

Singerman, A. 2015b. 2014/15 Indian River Cost of Production for Fresh Grapefruit. Lake Alfred, FL: University of Florida Institute of Food and Agricultural Sciences. http://www.crec.ifas.ufl.edu/extension/economics/ pdf/2014_15\%20IR\%20Costs.pdf 
Table 1. Real costs of production for southwest Florida processed oranges: 2003/04 versus 2014/15

\begin{tabular}{|c|c|c|c|c|c|}
\hline \multirow[t]{2}{*}{ Program } & \multicolumn{2}{|c|}{ 2003-04 } & \multicolumn{2}{|c|}{ 2014-15 } & \multirow[t]{2}{*}{ Change } \\
\hline & $\$ /$ Acre & $\%$ of Total & $\$ /$ Acre & $\%$ of Total & \\
\hline Weed management & 233.31 & 24.90 & 248.19 & 15.03 & $6 \%$ \\
\hline Foliar sprays & 185.63 & 19.81 & 666.00 & 40.33 & $259 \%$ \\
\hline Fertilizer & 207.69 & 22.17 & 486.96 & 29.49 & $134 \%$ \\
\hline CHMAs sprays & - & - & 20.55 & 1.24 & - \\
\hline Pruning & 38.78 & 4.14 & 31.50 & 1.91 & $-19 \%$ \\
\hline Irrigation & 271.47 & 28.98 & 198.14 & 12.00 & $-27 \%$ \\
\hline Total without tree replacement & 936.87 & 100.00 & $1,651.34$ & 100.00 & $76 \%$ \\
\hline Tree replacement & 145.98 & 13.48 & 346.77 & 17.35 & $138 \%$ \\
\hline Total with tree replacement & $1,082.85$ & - & $1,998.11$ & - & $85 \%$ \\
\hline
\end{tabular}

Table 2. Real costs of production for Indian River fresh market grapefruit: 2003/04 versus 2014/15

\begin{tabular}{|c|c|c|c|c|c|}
\hline \multirow[t]{2}{*}{ Program } & \multicolumn{2}{|c|}{ 2003-04 } & \multicolumn{2}{|c|}{ 2014-15 } & \multirow[t]{2}{*}{ Change } \\
\hline & $\$ /$ Acre & $\%$ of Total & $\$ /$ Acre & $\%$ of Total & \\
\hline Weed management & 270.40 & 19.78 & 196.60 & 8.75 & $-27 \%$ \\
\hline Foliar sprays & 493.08 & 36.08 & $1,300.40$ & 57.86 & $164 \%$ \\
\hline Fertilizer & 190.56 & 13.94 & 452.55 & 20.14 & $137 \%$ \\
\hline CHMAs sprays & - & - & 14.75 & 0.66 & - \\
\hline Pruning & 59.57 & 4.36 & 78.90 & 3.51 & $32 \%$ \\
\hline Irrigation & 271.47 & 19.86 & 117.83 & 5.24 & $-57 \%$ \\
\hline Canker control & 81.67 & 5.98 & 86.40 & 3.84 & $6 \%$ \\
\hline Total without tree replacement & $1,366.75$ & 100.00 & $2,247.43$ & 100.00 & $64 \%$ \\
\hline Tree replacement & 182.47 & 11.78 & 231.18 & 9.33 & $27 \%$ \\
\hline Total with tree replacement & $1,549.22$ & - & $2,478.61$ & - & $60 \%$ \\
\hline
\end{tabular}

